\title{
Shifting policies, access, and the tragedy of enclosures in Ecuadorian mangrove fisheries: towards a political ecology of the commons
}

\author{
Christine M. Beitl ${ }^{1}$ \\ University of Georgia, USA
}

\section{Introduction}

Over the last several decades, a large percentage of coastal mangrove wetland forests in Ecuador have been cleared for the development of shrimp aquaculture despite the existence of forestry laws protecting mangroves since the 1980s. The current Ecuadorian Forestry Law stipulates that mangroves are public goods of the State, "not subject to possession or any other kind of appropriation, and can only be exploited by way of authorized concession." ${ }^{2}$ Since 1985, the cutting, burning, and exploitation of mangroves has been prohibited (Bravo 2007: 27). These policies were weakly upheld in light of export-led growth and global demand for cheap shrimp cocktail that drove the conversion of public mangrove areas into private shrimp farms throughout Ecuador and many other parts of the developing world, resulting in widespread environmental degradation, welfare impacts, and social conflict (Bailey 1988; Stonich 1995; DeWalt, Vergne, and Hardin 1996; Primavera 1997; Cruz-Torres 2000; Stonich and Vandergeest 2001; Gunawardena and Rowan 2005; Lutz 2006) and what Martinez-Alier (2001) has called a "tragedy of enclosures." However, in 1999, White Spot Syndrome Virus, a disease in cultured shrimp, halted the further expansion of shrimp ponds into vital mangrove habitat. By the year 2000, the Ecuadorian State began to recognize the "ancestral" rights of "traditional user groups" to mangrove resources, paving the way for custodias, ten-year community-managed concessions. As of July 2011, a total of 37,818 hectares have been granted to 41 different communities as part of the national strategy toward community-based conservation and management of mangrove resources (Rosero Moya and Santillan Salas 2011). After decades of struggle and conflict between shrimp farmers and artisanal fishers who have lost their fishing grounds to aquaculture, fishing communities in Ecuador now have the legal backing to defend their livelihoods, guard their mangroves against further destruction, and promote sustainable mangrove fisheries. This article will demonstrate, however, that the establishment of custodias has changed the nature of the struggle over mangrove resources from artisanal fishers versus shrimp farmers to a struggle between compañeros, those who have custodias and those who do not.

Given recent concerns about overexploitation in recent decades and its likely relationship to shrimp farming (Ocampo-Thomason 2006; C-CONDEM 2007), I focus on the fishery for the mangrove cockle (Anadara tuberculosa and A. similis), a bivalve mollusk harvested from the roots of mangrove trees by artisanal fishers. The general aim of this study is to bridge theoretical perspectives from political ecology and commons theory to evaluate shifting policies and the implications for social relations among mangrove fishers in Ecuador. While the establishment of common property arrangements under government-granted custodias appears to promote sustainable cockle collecting, the very custodias designed to empower local communities in defense against mangrove destruction may now serve as a new form of enclosure that denies access to independent cockle collectors not affiliated with any local association and further threatens to undermine the ecological sustainability of the fishery (Beitl 2011). As also pointed out by O'Flaherty (2003), it is important to not only consider the relationships between local communities and their local ecologies as discrete areas governed by a set of property relations, but also the larger socio-ecological and historical context in which those property regimes are embedded. Furthermore, property relations only represent one

\footnotetext{
1 Ph.D. candidate, Department of Anthropology, University of Georgia, USA. Email: cbeitl "at" uga.edu. I am indebted to all the Ecuadorian cockle collectors, government officials, scientists, and NGOs who made this study possible. This work was carried out with financial support from the National Science Foundation Doctoral Dissertation Improvement Grant (BCS-0819376), Wenner Gren dissertation fieldwork grant, and the Fulbright IIE Fellowship program. I am grateful to my dissertation committee for their invaluable support through the multiple stages of my dissertation research, and particularly Dr. Julie Velasquez-Runk, Dr. Bram Tucker, and Heather Gallivan for their constructive feedback on the early drafts of this paper. Many thanks also go to the Eric Wolf Prize committee. All errors and shortcomings within this manuscript are my own. This paper was joint winner of the Eric Wolf Prize, Political Ecology Society, 2011 and appears in a JPE Special Section of Eric Wolf Prize papers edited by Joe Heyman.

2 (Author's translation). The original text of the Forestry Law Titulo 1, Capitulo 1, Art. 1 published in Registro Oficial No. 418 (September 10, 2004) states: "Los manglares, aun aquellos existentes en propiedades particulares, se consideran bienes de Estado y están fuera del comercio, no son susceptibles de posesión o cualquier otro medio de apropiación y solamente podrán ser explotados mediante concesión otorgada, de conformidad con esta Ley y su reglamento."
} 
set of mechanisms by which actors gain, control, and maintain access to resources, which is highly likely to shift over time, thereby affecting the ability of people to benefit from resources (Ribot and Peluso 2003).

I begin this discussion by reviewing the literature on the commons, property rights, and access, making the case why the political ecology perspective is relevant to the study of the commons. Then I discuss two important economic sectors in Ecuadorian mangrove forests, the shrimp farming sector and the artisanal mangrove fishery sector, and the degradation narrative that has linked them together (C-CONDEM 2007). In my examination of policy shifts from an implicit preference for shrimp aquaculture development to the recognition of ancestral rights of artisanal fishers, I analyze the social and ecological implications of the common property institutional outcomes associated with custodias for the artisanal fishers the concessions were originally designed to protect and defend. I conclude by suggesting a need to develop a political ecology of the commons, a domain of inquiry that has not been explicitly discussed in the literature. A political ecology approach can elucidate the ways in which material struggles over access to common pool resources tend to shift in response to changing policies, which is best illustrated in the case of the Ecuadorian mangrove cockle fishery. Such broader understanding of the socio-political dimensions of social relations of the commons can provide important insights for policies moving toward integrated coastal management through decentralization and community participation (Robadue 1995; Olsen and Christie 2000; Olsen, Ochoa, and Robadue 2003; Christie 2005).

\section{The commons, property rights, and access through a political ecology lens}

Much of the literature on common pool resources has pointed to two defining characteristics that make them difficult to manage: 1) subtractability, referring to the way that resource extraction by one user takes away from the ability of another user to maximize his/her potential gain; and 2) excludability, or difficulty in keeping away outsiders (Buck 1998; Ostrom et al. 1999). Because of these characteristics, different types of commons (grazing lands, forests, fisheries, wetlands, oceans, the atmosphere) have been considered vulnerable to collapse based on assumptions widely popularized by the tragedy of the commons model, that humans exploit the commons to maximize their personal gain without any form of social organization, communication, or consideration for other users (Gordon 1954; Hardin 1968). One of Garrett Hardin's (1968) solutions to the tragedy was to create ownership through property rights and privatization that would hypothetically give people the necessary incentives to protect resources. Over the last several decades, the tragedy of the commons model has provoked widespread reaction and discussion about property rights in various disciplines concerned with the governance of the commons (see for example, McCay and Acheson 1987; Ostrom 1990; Bromley and Feeny 1992; Hanna, Folke, and Mäler 1996; Ostrom et al. 1999; Gibson, McKean, and Ostrom 2000; Agrawal 2001; Dolsak and Ostrom 2003; Berkes 2005).

Property rights are defined broadly as a set of social relations, mutually recognized claims and decision-making powers over resources (Gibson, McKean, and Ostrom 2000; Wagner and Davis 2004). Property regimes are the structures or institutions that define the rules of use of resources and interactions between people (Bromley and Feeny 1992; Agrawal and Gibson 1999), and are among the many institutions in society that influence human interaction, economic performance, and development (North 1990) in their ability to either promote or inhibit the stewardship of environmental resources (Hanna and Munasinghe 1995). Common property has been defined as a social institution distinct from open access, private, or government-owned property (Feeny et al. 1990; Ostrom et al. 1999). In common property regimes, resource use rights are "controlled by an identifiable group" in a system of "collective ownership" (Satria, Matsuda, and Sano 2006: 228). As argued by McKean (2000), common property regimes function much like private property, except that ownership is shared. The distinction between these property regime categories is essentially conceptual since resource systems are often hybrid regimes or mixed systems in reality (Feeny et al. 1990; Wagner and Davis 2004; Satria, Matsuda, and Sano 2006; Beitl 2011).

Others have pointed out that commons systems are essentially "embedded" cultural systems, not adequately understood by rational choice economics or institutional frameworks (Wagner and Davis 2004; Peters 1987). As embedded cultural systems, resource users are motivated to sustain their social relations and cultural meanings in the interest of their livelihoods and the resource bases upon which their livelihoods depend, and access rights are maintained through regular use (Wagner and Davis 2004). Such embedded systems are reflective of many customary marine tenure regimes throughout the Pacific Islands and traditional fisheries throughout the world (Johannes 1978, 2002; Acheson 1987; Mera Orcés 1999; Thomas 2001; Wagner and Talakai 2007; Cinner 2005).

External threats and internal breakdown of common property regimes due to migration, markets, policy change, or unfavorable policy environments in favor of private or government control have long been a concern within the literature on the commons and traditional management systems (Johannes 1978; Richards 1997; McKean 2000; Curran and Agardy 2002; Acheson and Brewer 2003; Cinner 2005). Greenberg (2006) has suggested a "tragedy of commoditization" rather than a tragedy of the commons in the case of the Upper California Gulf fisheries where certain resources have been privileged over others through the process of zoning or territorialization of management regimes. Similar to the "tragedy of enclosures" argument proposed by Martinez-Alier (2001), Greenberg highlights the contradictions of capitalism in which 
growth driven by global demand undermines the very sustainability of the resource base, an observation also made by Parks and Bonifaz (1994) in the case of Ecuadorian shrimp farming. According to Greenberg, the tragedy begins when nature is dispersed across multiple governance structures into discrete management regimes privileging political and economic principles over a more holistic ecosystem approach to management. O'Flaherty (2003) has also pointed out the problems with discrete management zones in the case of communal land tenure in Zimbabwe, suggesting that a "tragedy of property" results from the legacy of a colonial political economy that undermines African land use within communal tenure systems.

For the reason that much of the common property literature emerged as a polemic to Garrett Hardin's tragedy of the commons (McCay and Acheson 1987; Bromley and Feeny 1992), many studies have uncritically assumed the existence of community-based environmental stewardship without challenging the notion that cooperation is always in the interest of conservation or studying the direct link between social and ecological systems to support those claims (Berkes 1996; Ruttan 1998; Lu 2001; Pollnac and Johnson 2005; Beitl 2011). As McCay and Acheson have pointed out, there has been a "tendency to romanticize human communities" for their imagined foresight and ability to overcome resource dilemmas (McCay and Acheson 1987: 10). Given these tendencies, it is important to understand property rights systems from multiple perspectives to design and implement conservation and management strategies for governing the commons (Ostrom 1990; Bromley and Feeny 1992; Hanna, Folke, and Mäler 1996; Ostrom et al. 1999). However, as Ribot and Peluso (2003) contend, a focus on property rights only offers a limited understanding of how benefits are derived from resources and suggest instead, a theory of access, in which structural social inequities are considered.

Ribot and Peluso (2003) argue that the concept of access differs from property rights in many ways. Property rights are only one mechanism for obtaining access. The authors define access as "the ability to benefit from things-including material objects, persons, institutions, and symbols" (Ribot and Peluso 2003: 153). Regarding access to resources, they argue that there are different powers involved that are subject to shift over time, based on one's position and power within a social relationship. Thus access is a process by which social relations and differentiation emerge from cooperation and conflict over resources in particular situations in which new legal frameworks potentially arise (Ribot and Peluso 2003: 160). Wagner and Davis (2004) illustrate the notion of access as a process in their discussion of the contemporary lobster fishery in northeastern Nova Scotia where individual fishers stick to their preferred spots occasionally acquiring access to other territories by branching out in the common grounds not regulated under the traditional Berth system. Enclosure of the commons and the blocking of access is also described as a process by Murray and others, and of particular relevance to the burgeoning fisheries literature concerned with limited entry, catch-share programs, and individual transferable quota systems (Murray et al. 2010). Similarly, access is also highly relevant to the study of mangrove concessions in Ecuador managed by the communities as common property regimes where the exclusion of outsiders is enforced.

Few studies have examined common property institutions as political agents in their own right, that maintain power, authority, and control over territory and resources (Reddy 2002). The political ecology literature has been concerned with ideational and material struggles over resources and the role of power, discourse, policy, and science in shaping the outcomes of those struggles (Wolf 1972; Blaikie and Brookfield 1987; Bryant 1992; Greenberg and Park 1994; Zerner 2000; Stott and Sullivan 2000; Peluso and Watts 2001; Forsyth 2003; Peet and Watts 2004; Paulson and Gezon 2005; Biersack and Greenberg 2006). Armitage (2002) has used the approach to study mangrove conservation in Indonesia, suggesting that the policy narrative does not always match its implementation, calling for a need to monitor processes at various levels. Several scholars have used political ecology to analyze linkages between global and local processes in the study of the relationship between shrimp farming, mangroves, and local communities (Stonich 1995; CruzTorres 2000; Stonich and Bailey 2000; Martinez-Alier 2001; Stonich and Vandergeest 2001). The goal of this article is to evaluate how coastal policies shifted from an implicit preference for shrimp industry development to one focused on sustainable development with greater participation by ancestral coastal communities, and how those policy shifts have changed the nature of property rights, the distribution of resources, and access among artisanal fishers dependent upon mangrove fisheries in Ecuador. A political ecology lens is appropriate for studying this process since property rights, by definition, are a set of social relations, which are cooperative, conflictive, hierarchical, divisive, power-laden, political, and constantly in flux. Using the framework for studying access proposed by Ribot and Peluso (2003), I will demonstrate in the following sections the ways in which social inequities and shifting access may be an important underlying factor contributing to the tragedy of enclosures in the Ecuadorian mangrove cockle fishery.

\section{Shrimp and shifting access in the Ecuadorian mangrove fishery commons}

Mangroves in Ecuador have played an important role in the development of communities throughout history. Around the world, mangroves traditionally supply a variety of goods, including fish, mollusks, crustaceans, timber, charcoal, construction materials, medicinal goods, tannin, honey, incense, thatch, fuel wood, paper, and dyes for cloth (Snedaker 1986; Kovacs 1998; Ronnback 1999; Acharya 2002; Glaser 2003; Walters et al. 2008). In Ecuador, mangroves have not only traditionally been a source of fish, mollusks and 
crustaceans, but the wood has also provided charcoal, fuel wood, and construction materials for boats, homes, bridges, piers, and traditional fishing gear and traps (Mera Orcés 1999; CLIRSEN-PMRC 2007). In addition to the direct uses described above, mangroves provide numerous environmental services such as nutrient cycling, erosion control, sediment trapping, groundwater re-charge, water purification, storm surge/tsunami protection, carbon sequestration, micro-climate stabilization, biodiversity support, and habitat/ nursery service for commercial, recreational, and subsistence fisheries (Ronnback 1999; Upadhyay, Ranjan, and Singh 2002; Barbier 2003; Brander, Florax, and Vermaat 2006) . There are four prominent mangrove tree genera in Ecuador: Rhizophora, Avicennia, Conocarpus, and Laguncularia, whose protection has been mandated since 1985 (CLIRSEN-PMRC 2007). Prior to the development of the shrimp industry, mangrove areas were enjoyed by tens of thousands artisanal fishers as a public good.

Traditionally, mangrove cockles are harvested from the roots of mangrove trees for subsistence and domestic markets by women and children in the province of Esmeraldas and by men and young boys throughout the rest of the country. Presently, shells gathered in El Oro Province (Figure 1) are destined for export to Peru resulting in higher earnings for the collectors in El Oro (\$12-20 per 100 shells) than in Esmeraldas (\$6-12 per hundred shells). Prices are subjectively determined by the "quality" of the catch (larger shells and catches with a greater proportion of $\mathrm{A}$. tuberculosa are sold for a higher price also depending on demand and seasonality). Prices are sometimes intensely negotiated between the collector and the buyer depending on their relationship to one another. ${ }^{3}$

\section{SHRIMP FARMS AND MANGROVES IN EL ORO PROVINCE}

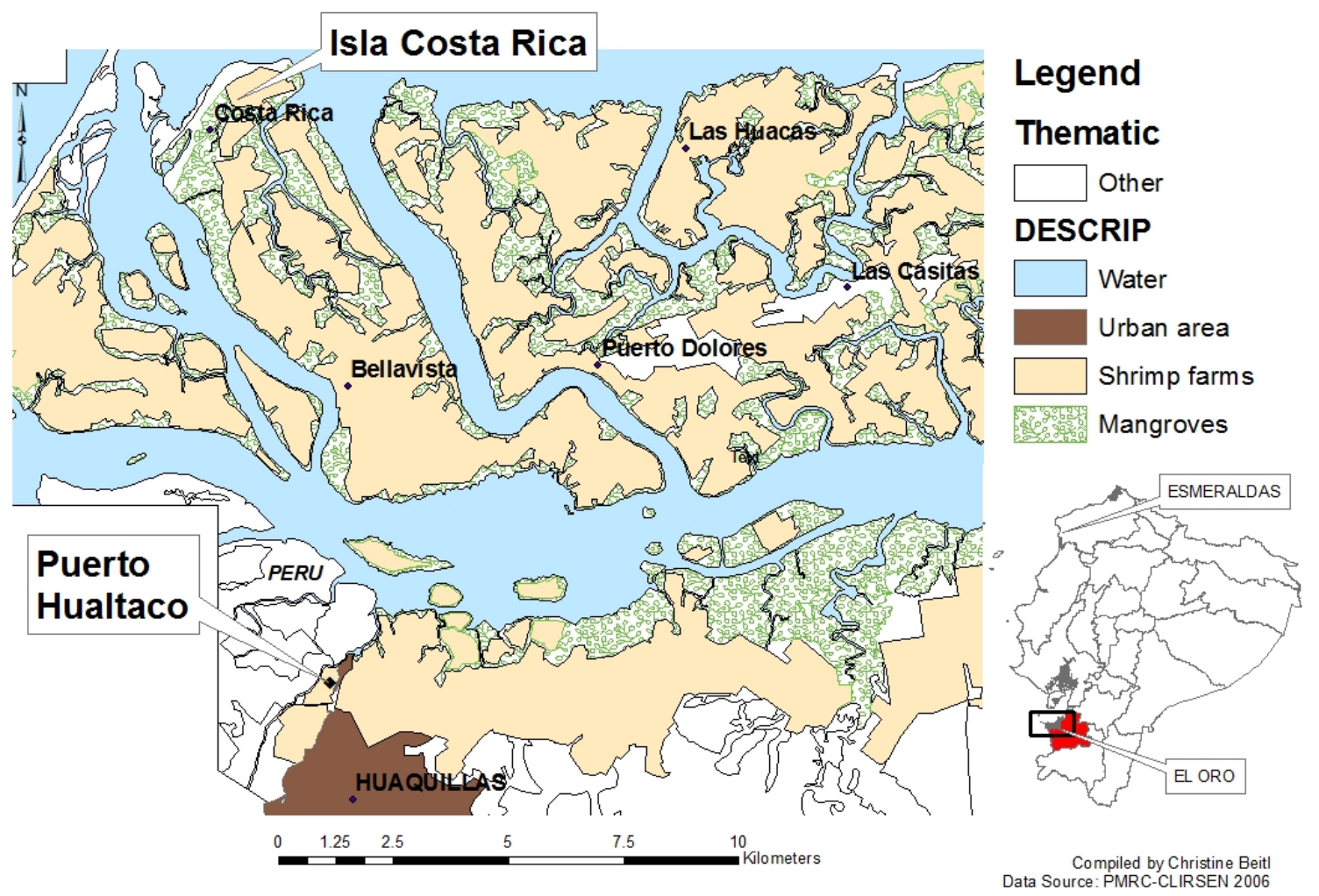

Figure 1: Shrimp farming and mangroves in the two study areas, Isla Costa Rica and Puerto Hualtaco in El Oro.

The first records of the cockle fishery's commercialization date back to the 1970s in a census conducted by the Instituto Nacional de Pesca (INP 1971). In the last 10 years, studies have begun to show

\footnotetext{
3 Many cockle collectors consistently sell their shells to the same person, either a relative or close friend. Others may alternate their sale of shells between different buyers opportunistically taking the best offer.
} 
declining catch and shell sizes in Ecuador (Elao and Guevara 2006; Mora and Moreno 2009; Mora, Moreno, and Jurado 2009) and throughout their range from Mexico to Peru (MacKenzie 2001). Under the recommendations of the Instituto Nacional de Pesca (INP), the Subsecretaría de Recursos Pesqueros (SRP) established the first measures to regulate the fishery in 2001 by implementing a closed season and permanent prohibition on the capture of cockles smaller than $45 \mathrm{~mm}$ in length. In the communities that have been granted mangrove concessions, local rules of fishery management have been implemented for sustainable harvest of mangrove resources (Ocampo-Thomason 2006; Bravo 2007; Coello, Vinueza Burgos, and Alemán 2008; Ecobiotec 2009). Fundación de Defensa Ecológica (FUNDECOL) and Coordinadora Nacional para la Defensa del Ecosistema Manglar (C-CONDEM), two environmental organizations for the defense of mangroves and livelihoods, have attributed the recent decline of the fishery to predatory capitalism practiced by the shrimp industry in Ecuador.

Shrimp aquaculture in Ecuador began as early as 1966 with rudimentary forms of culturing shrimp in tidal pools, taking advantage of the natural hydrologic processes and tidal fluctuations, and subsequently grew in response to international demand and the profitability of the industry (CLIRSEN-PMRC 2007). Since then, investments in technology, knowledge and infrastructure allowed the industry to expand into salt flats, upland brush areas (matorral), and agricultural/ pasture lands (agropecuaria) before "indiscriminately" encroaching on mangrove habitat (CLIRSEN-PMRC 2007: 3). This resulted in widespread environmental degradation and social conflict (Bailey 1988; Southgate and Whitaker 1994; Ocampo-Thomason 2006; CCONDEM 2007; CLIRSEN-PMRC 2007), eventually raising concerns about the sustainability of the industry itself since shrimp depend on mangroves for a portion of their life-cycle (Parks and Bonifaz 1994).

By the mid-1980s, shrimp farms were expanding throughout the Archipiélago Jambelí in the province of El Oro and the Muisne-Cojimíes estuary in Esmeraldas. On a national level, 26.5\% of mangroves have been converted into shrimp farms since 1985, with some estuaries deforested from $74.6 \%$ (Muisne) up to 90.2\% (Chone) (Bravo 2007). Between 1969 and 1995, the Archipiélago Jambelí in the province of El Oro had lost almost half of the original mangrove cover (Bravo 2006). Often compared to "gold rush" fever in other parts of the developing world (Cruz-Torres 2000; Jermyn 2000), the shrimp industry in Ecuador expanded rapidly in both geographical extent and political power, disrupting environmental services and displacing artisanal fishers (Figure 2) while producing one of the nation's top exports along with bananas and oil. Artisanal fishers with little political power or and economic resources could do very little but to stand by and watch their fishing grounds be bulldozed away. In this research, some informants regretfully admitted to me in interviews that they were part of the destruction process. In the early years of development, many artisanal fishers and shell collectors in Muisne took employment with shrimp companies to help in the construction of shrimp ponds without realizing the potential consequences of mangrove deforestation for their own livelihoods. Promoted by national governments around the world and supported by international banks and lending agencies, usually only the local elite and outsiders have had access to the credit, knowledge, and technology needed for the development of a shrimp farm, further exacerbating structural inequalities of wealth and power (Bailey 1988; Cruz-Torres 2000; Martinez-Alier 2001).

As shrimp mariculture rapidly spread in coastal zones throughout the world, the Ecuadorian shrimp industry has been considered one of the most successful cases for its increase in production and foreign exchange earnings over a relatively short period of time, ultimately surpassing the trawl industry (Bailey 1988). However, the growth of shrimp ponds from 89,368 ha in 1984 to 178,071 ha in 1995 just before the industry crashed in 1999 corresponds with the decrease in mangrove cover from 182,157 ha in 1984 to 146,938 ha in 1995 (CLIRSEN-PMRC 2007). ${ }^{4}$ Despite the social and ecological consequences associated with mangrove deforestation and shrimp aquaculture documented in the literature, Ecuador is also unique for its progressive policies toward coastal management and the institutions dedicated to the implementation of integrated coastal management (Robadue 1995; Olsen, Ochoa, and Robadue 2003). While there has been some critique (Guest 1999), the Programa de Manejo de Recursos Costeros (PMRC, or coastal management plan) as been an important institution behind the design and implementation of policies related to conservation and development in coastal communities. Policies have shifted from a focus on shrimp farming development to sustainable development with community participation. The progressive policies on coastal management reflect broader trends in Ecuador which became the first country in the world to recognize the rights of nature in its constitution by 2008 (Mychalejko 2008; Acosta and Martinez 2009). It is within this context I examine the way in which mangroves have been "appropriated" under different property regimes that have denied access to formerly public goods, potentially undermining the sustainability of mangrove fisheries.

\footnotetext{
${ }^{4}$ The figures for 1999 are not reported here because of possible technical errors in measurement associated with the acquisition of additional aerial photos that increased the extent of the study area (for an explanation, see CLIRSENPMRC 2007: 29). Such figures showing a significant increase in mangrove cover between 1995 and 1999 during the height of the shrimp industry's production and success are questionable.
} 

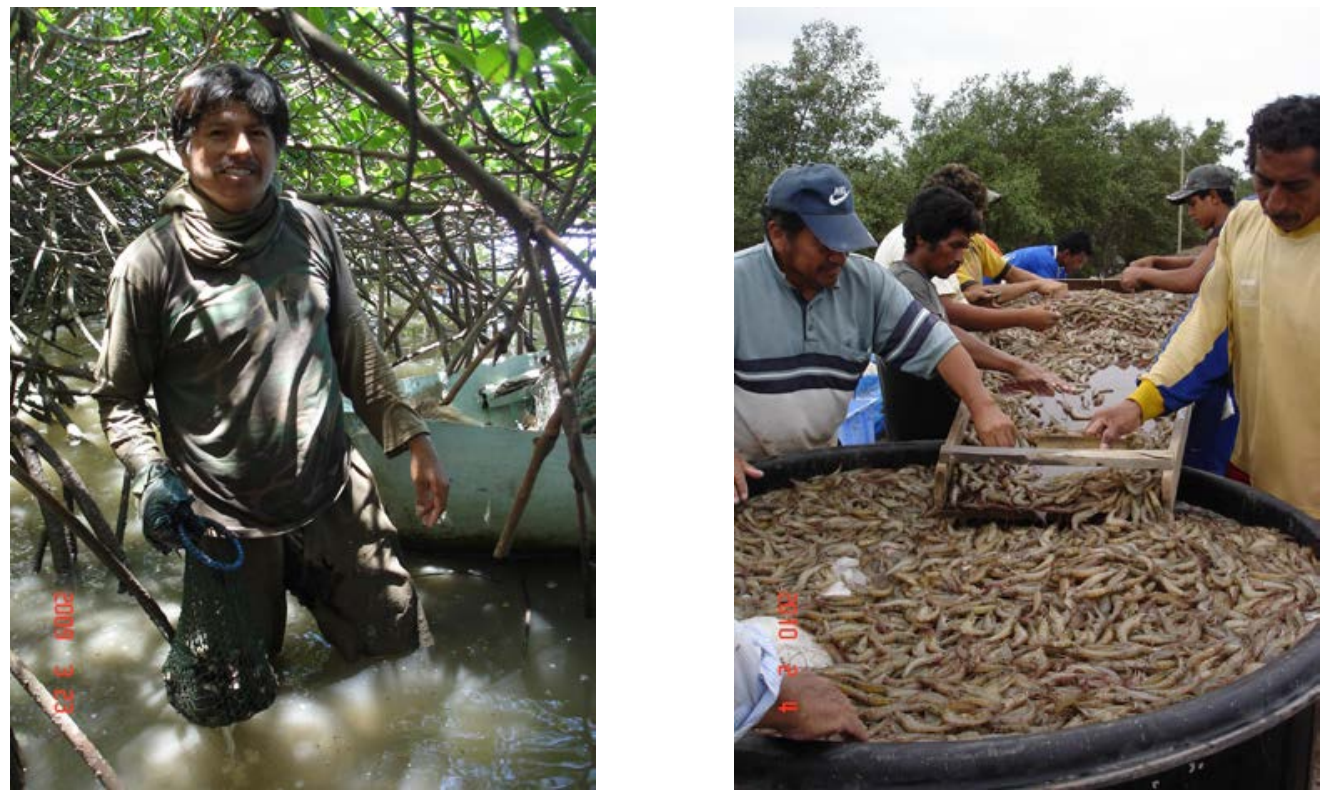

Figure 2: a) A cockle collector from Isla Costa Rica, El Oro with his total catch (left). b) A smallscale family shrimp farm in Muisne, Esmeraldas (right). While shrimp farms are designed to scale up production for surplus and export, the products from natural mangroves are estimated by FUNDECOL and C-CONDEM to support ten times the number of families compared to a smallscale shrimp farm. *All photos by author unless noted otherwise.

\section{Methods for studying shifting access within Ecuadorian mangrove commons}

My argument draws on field research from January 2009 to December 2010 and during the summers of 2006 and 2008. I carried out exploratory interviews and observations in thirteen sites in two provinces (eight sites in El Oro Province and five sites in Esmeraldas Province), before selecting four sites to collect catch-per-unit-effort (CPUE) data and administer semi-structured questionnaires for cockle collectors: Isla Costa Rica and Hualtaco in the province of El Oro and Muisne and Las Manchas in the province of Esmeraldas. ${ }^{5}$ All of the research sites in Esmeraldas and El Oro were heavily affected by mangrove deforestation and shrimp farming until the late 1990s when the white spot virus hit the industry. The focus of this analysis is in the two El Oro sites (Figure 1) where "custodias have been spreading like a fever now that everyone is asking for a concession" (Mora, personal communication).

Since 2003, the Muisne-Cojimíes estuarine system in the province of Esmeraldas has been protected by the Refugio de Vida Silvestre under the management and vigilance of the national park service and FUNDECOL, a grassroots environmental organization working in Muisne since 1989. In contrast, many mangrove areas in the province of El Oro have been protected by custodias, or agreements for the sustainable use and stewardship of mangroves. As of July 2011, the Subsecretaría de Gestión Marina y Costera authorized sixteen mangrove concessions in El Oro, amounting to 4,002 hectares of community protected mangroves. Isla Costa Rica, one of the study sites for this research, was one of the first communities in the country to receive a custodia in the year 2000. Many cockle collectors living in the city of Huaquillas/ Puerto Hualtaco are originally from the communities of the archipelago but have lost their ancestral rights to the custodias in their native communities for having migrated out. Several local associations in Hualtaco have asked the government for a concession, but at the time of this research, only two had been granted to Isla Costa Rica and Las Huacas (see figure 1). The perceptions by members of local associations and other cockle

\footnotetext{
${ }^{5}$ Sites for exploratory interviews and observations in El Oro included the communities of Isla Costa Rica, Las Huacas, Bellavista, Casitas, and Pongalillo and the ports of Hualtaco, Bolivar, and Jeli. Sites visited in Esmeraldas included Muisne, Las Manchas, Bunche, San Jose de Chamanga, and San Lorenzo. I would like to express my gratitude to several individuals at five institutions for helping to orient me to different sites, introducing me to key informants, and in some cases, assisting with travel: Elba Mora and Juan Moreno at Instituto Nacional de Pesca, Adolfo Cruz and Miguel Cruz from Asociacion de Mariscadores, Pescadores Artesanales y Afines "Costa Rica", Rafael Elao at Ecocostas, Wellington Angulo Banega and Frank Navarrete from FUNDECOL, and Bolivar Gamboa at the the Ministerio de Ambiente office in Muisne.
} 
collectors that total catches and shell sizes are larger in the custodias have been confirmed by this research (Beitl and Cruz 2010; Beitl 2011).

In Isla Costa Rica, I worked closely with the president of the Asociación Isla Costa Rica, Don Adolfo Cruz, who played an instrumental role in helping me to coordinate research activities and motivate the participation of other cockle collectors on the island. In Muisne and Las Manchas, my key informant and guide was a recent high school graduate, Adrian Vargas, son of a local fisherman and merchant who transports cockles and other mangrove products to neighboring communities. Adrian's mother is a housewife and former member of a now inactive local association of female cockle collectors. In addition to observations, mapping exercises, oral histories, and collection of catch-per-unit-effort (CPUE) data, I conducted interviews with 153 cockle collectors, fishers, women, and community leaders. The questionnaire for cockle collectors was divided into five sections: 1) informed consent; 2) information about cockles, including CPUE, shell size measurements, description of the site of extraction and means of transport; 3 ) perceptions of change in mangroves and the fishery; 5) participation in civil society activities, social movements, and other forms of collective action. I asked cockle collectors about whether they ever had a conflict with a shrimp farmer or another cockle collector and whether they believed that shrimp farming and artisanal fishing were compatible. In El Oro where custodias are present, I asked informants for their general opinion about effectiveness and whether they felt people respected the property lines. To evaluate the impacts of custodias on social relations among cockle collectors, I coded the answers of the interview questions and conducted a two-way cross-tabulation to test for significant differences in responses between the two provinces using the Fisher's exact test. Finally, I conducted focus groups for informants and local associations in all four sites to present the preliminary results of my study and discuss issues of overexploitation and territoriality within the cockle fishery.

To gain a broader understanding of the evolution of coastal management policy and recent socialecological changes in the last four decades, I consulted a number of policy reports, laws, presidential decrees, ministerial agreements, and scientific studies by NGOs, research institutions, and scholarly articles. I interviewed government officials, merchants of mangrove products, shrimp farmers, activists, and scientists from different NGOs, research institutes, local cooperatives and associations, and various government agencies concerned with mangroves, artisanal fisheries, and/or aquaculture. ${ }^{6}$ In the interviews, I enquired about the history of conflict between shrimp and mangroves and about the effectiveness of custodias. In addition to these methods, I acquired much understanding about context from unplanned, informal discussions, participant observation, and focus groups with local fishing associations in Muisne and Puerto Hualtaco.

\section{Shifting policy and local impacts in the Ecuadorian mangrove commons}

\section{Conflict in the Commons}

As discussed in previous sections, shrimp aquaculture encroached on highly productive mangrove ecosystems throughout the 1980s and 1990s due to weak enforcement of policies protecting mangroves from destruction. In both provinces, about half of my informants reported having had a conflict with a shrimp farmer (Table 1). ${ }^{7}$ In many cases, they spoke on behalf of other "ancestral users" in solidarity with the group, expressing that they personally had not experienced a conflict, but their compañeros had. Most personal conflicts involved a verbal argument with the guard involving accusations of theft or trespassing. Occasionally, guards had been known to fire shots, and in a worst-case scenario, someone had been hurt or killed. However, a few informants pointed out that the guards are not the problem; rather it is the guard dogs that do not recognize the difference between a legitimate cockle collector and a thief (see figure 3). One shrimp farmer from Muisne suggested that the dogs are a way to avoid conflict, because if the dogs do not deter the collector, then a violent confrontation would be sure to break out.

Many informants pointed out that direct and violent confrontation between artisanal fishers and shrimp farmers was mostly a problem of the past. In the early years of shrimp farm expansion, local communities formed alliances with environmental activists to destroy the walls and dikes of the shrimp

\footnotetext{
${ }^{6}$ I owe my gratitude to several institutions for their collaboration: Instituto Nacional de Pesca, Subsecretaría de Gestion Marina y Costera, Ministerio de Ambiente, Subsecretaría de Recursos Pesqueros, Subsecretaría de Acuacultura, Ecocostas, C-CONDEM, FUNDECOL, Arcoiris, Ecobiotec, CLIRSEN, Escuela Superior Politécnica del Litoral, Universidad Técnica de Machala, Junta Parroquial de Isla Costa Rica, Alcaldaria de Muisne, Cultivadores de Especies Bioacuáticas de la Provincia de Esmeraldas (ACEBAE), Jatun Sacha - Congal, Federación de Pescadores Artesanales Frontera Sur, Federación de Usuarios Ancestrales del Ecosistema Manglar, and several local associations in El Oro and Esmeraldas, particularly Asociación Isla Costa Rica.

${ }^{7}$ See Beitl (2011) for differences between Isla Costa Rica and Puerto Hualtaco in the province of El Oro.
} 
ponds or threaten the staff with machetes. Today conflicts with shrimp farmers are less common since many cockle collectors have made agreements or asked for special permission to work on the pond walls.
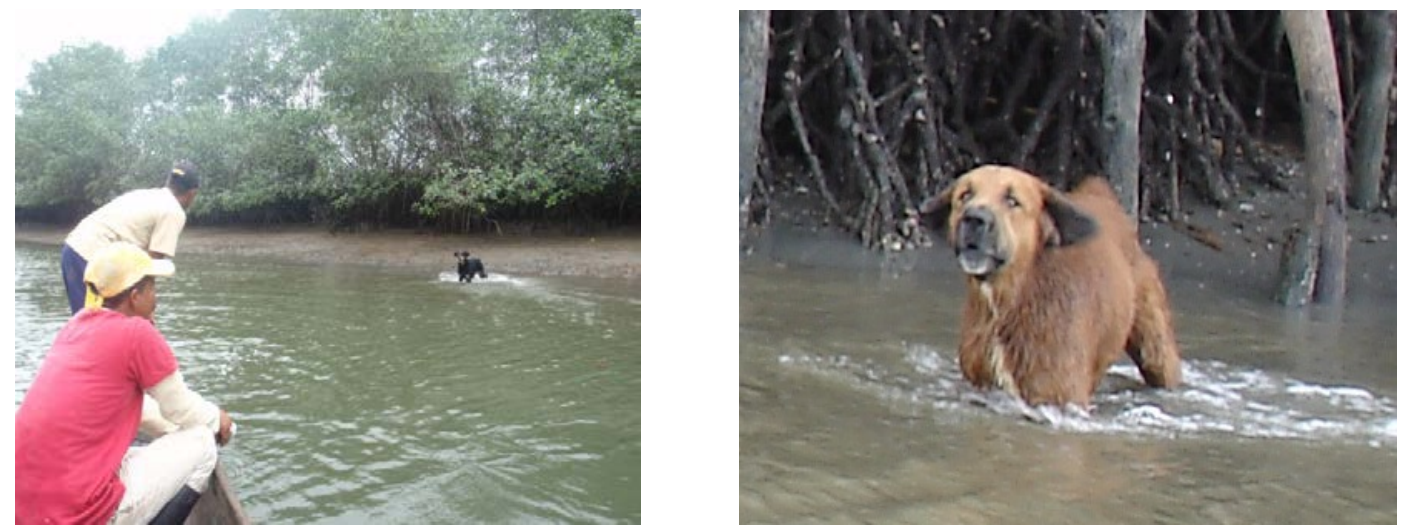

Figure 3: "Perros bravos" guard access to shrimp farms and deter cockle collectors and other artisanal fishers from getting too close and harvesting shells from the walls of a shrimp farm without special permission from the owner or guards on duty.

\begin{tabular}{|c|c|c|c|c|c|c|}
\hline & \multicolumn{2}{|c|}{ EL ORO } & \multicolumn{2}{|c|}{ ESMERALDAS } & \multicolumn{2}{|c|}{$\begin{array}{l}\text { Two-way cross- } \\
\text { tabulation measures } \\
\text { of association }\end{array}$} \\
\hline & $\begin{array}{l}\text { Percent that } \\
\text { agree }\end{array}$ & $\mathrm{N}$ & $\begin{array}{l}\text { Percent that } \\
\text { agree }\end{array}$ & $\mathrm{N}$ & $\begin{array}{l}\text { Chi } \\
\text { square }\end{array}$ & $p$-value \\
\hline $\begin{array}{l}\text { Shrimp farming is } \\
\text { compatible with artisanal } \\
\text { fishing }\end{array}$ & $47 \%$ & 64 & $30 \%$ & 43 & 2.964 & 0.064 \\
\hline $\begin{array}{l}\text { Had conflict with a } \\
\text { shrimp farmer? }\end{array}$ & $55 \%$ & 71 & $52 \%$ & 52 & 0.109 & 0.441 \\
\hline $\begin{array}{l}\text { Had conflict with another } \\
\text { cockle collector? }\end{array}$ & $49 \%$ & 71 & $12 \%$ & 52 & 19.256 & 0.000 \\
\hline Gathering grounds lost? & $96 \%$ & 72 & $84 \%$ & 49 & 5.217 & 0.049 \\
\hline $\begin{array}{l}\text { Gathering grounds lost } \\
\text { to shrimp farms? }\end{array}$ & $19 \%$ & 70 & $41 \%$ & 44 & 6.809 & 0.016 \\
\hline $\begin{array}{l}\text { Gathering grounds lost } \\
\text { to custodias? }\end{array}$ & $63 \%$ & 70 & $5 \%$ & 44 & 38.168 & 0.000 \\
\hline
\end{tabular}

Table 1: Informant responses to interview questions in El Oro and Esmeraldas ( $\mathrm{n}=153)$. 
In Puerto Hualtaco, new policies require cockle collectors to carry a government-issued ID card identifying them as an artisanal fisher, which they are occasionally asked to present to the shrimp farm guards, alleviating some of the tension.

In both provinces, informants generally agreed that they have lost their gathering grounds, but their explanations for lost gathering grounds differed depending on the province (Figure 4). In Muisne, Esmeraldas where there are no custodias, collectors mostly attributed the loss of gathering grounds to shrimp farms. ${ }^{8}$ By contrast, in El Oro, particularly in Puerto Hualtaco, most informants attributed the loss of gathering grounds to enclosure by custodias.

\section{Enclosure and exclusion by shrimp farms in the commons}

The "expropriation" of coastal resources has directly affected livelihoods and some people's ability to earn a living (Bailey 1988). According to FUNDECOL and C-CONDEM, a healthy mangrove system supports up to ten families for every one family a shrimp farm supports. While intensive production of shrimp greatly exceeds the production of cockles (see figure 2), most of it is for international export and very little remains for local and regional consumption. Many informants interviewed in this study were too young to remember the days that mangroves were bulldozed away and gathering grounds began to disappear in the 1980s, but had heard the stories from their parents. Other informants related their own observations of declining catches to pollution and effluents released from the ponds on a daily basis and the alleged illegal chemicals used to "clean" the pond of fungus and pests every three months after a harvest.

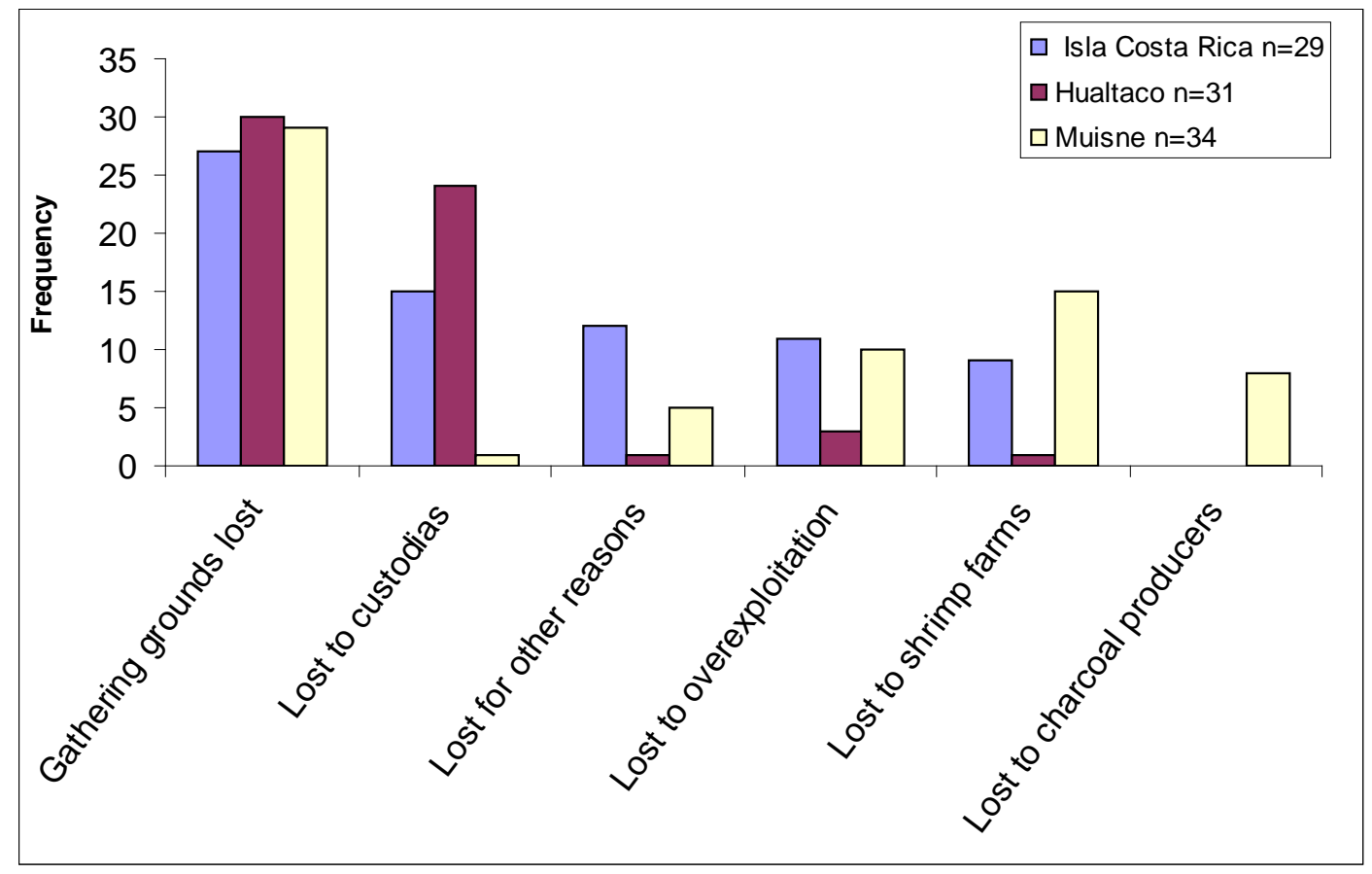

Figure 4: Local explanations for the loss of cockle gathering grounds by field site $(n=94)$. While there is general consensus among cockle collectors that gathering grounds have been lost, a chi-square test reveals significant differences between study areas in explanations for the loss of gathering grounds at the 0.05 level.

Another critique of the shrimp industry has been its failure to provide local economic benefits. Many of my informants commented that shrimp farmers often bring in their employees from outside, very rarely

\footnotetext{
8 The communities Las Manchas and Ostional are known by collectors in Muisne for their informal common property arrangements in which communities control access without holding a legal title or concession.
} 
offering full time employment to locals. ${ }^{9}$ These findings are similar to observations made by OcampoThomason (2006) in twelve communities of the Cayapas-Santiago-Mataje Rivers in Esmeraldas where shrimp farms only provided about $0.6 \%$ of local employment while $85 \%$ of households depended on mangrove fisheries. The failure of the industry to make a local economic impact was further confirmed in an interview with a shrimp farmer in Muisne who admitted to not hiring locals from the immediate vicinity for permanent positions as guards or managers for fear that they will encourage their local friends to steal. On the other hand, many of my informants in both provinces claimed that they were not interested in employment on shrimp farms. Some informants complained that the jobs were exploitative (many hours and low wages) and seasonal. Others commented they never had the chance because they were not "invited" to work during the harvest. Some informants in Isla Costa Rica were not interested in those jobs because they consider themselves fishermen, not "peons."

While local employment on shrimp farms tends to be seasonal and temporary, some people in rural communities benefited from profitable work in the collection of wild post larval shrimp (PLS) to stock the ponds during the boom years (Parks and Bonifaz 1994; Guest 2000) until the PLS fishery was closed for concerns about overexploitation of seed in 1999. Other sectors in packing, processing, and transportation flourished throughout the late 1980s and 1990s, mobilizing the migration of people to rural fishing villages and urban centers where the industry thrived. Places like Muisne urbanized once again after a hiatus from the boom-bust legacy of the banana industry during the 1960s. As urban centers, Muisne and Huaquillas/ Hualtaco benefited from the thriving shrimp industry until 1999 when the white spot virus devastated the industry, closing hatcheries, processing and packing plants, and halting infrastructural development. Many people displaced by the crash of the shrimp industry in 1999 had no other choice in a precarious economy but to take up artisanal fishing until other employment became available. Many of them are still fishing and collecting cockles to this day. Between the degraded mangrove habitats and increased number of fishers, artisanal fisheries like that of the mangrove cockle, began to decline.

\section{Changing policy and enclosure by custodia in the commons}

Within the context of conflict between shrimp farming and the artisanal fishery sector, the Programa de Manejo de Recursos Costeros (PMRC) was established in the 1980s under the Office of the President of the Republic of Ecuador. During the first phase from 1986-2004, with financial assistance from USAID and Inter-American Development Bank and technical assistance from the University of Rhode Island Coastal Resource Center, its mission was to "Improve the quality of life for communities that depend on coastal and marine resources and increase the contribution of those resources for the wellbeing of the national economy while maintaining biological diversity and the productivity of coastal-marine ecosystems" (Herrera Ximénez and Molina Bravo 2008). ${ }^{10}$ Recognizing the problems of mangrove degradation, decline in artisanal fisheries, inappropriate development, and a decline in water quality, many of their early efforts were focused on how to make shrimp aquaculture more sustainable (Odum and Arding 1991; Robadue 1995; Bordero and Retamales 2003; Macintosh and Ashton 2004). While the impacts of PMRC projects were not felt in many communities (Guest 1999), my informants in Muisne and Las Manchas remembered PMRC projects in positive light.

As the shrimp industry crashed in 1999 due to white spot virus, the idea to create custodias was born in the community of Bunche just outside Muisne during a conversation between PMRC biologists and an association of women cockle collectors who wondered why shrimp farmers were able to get concessions while mangroves remained an open-access public good for everyone else (Bravo, personal communication). Interestingly, neither Bunche nor any of the communities around Muisne have a government-granted custodia today. The majority are located throughout Archipiélago Jambelí in the province of El Oro and in the northern part of Esmeraldas in the communities around San Lorenzo that form part of the Mataje Cayapas Reserve.

In the second phase of the PMRC (2005-2009), with several custodias already granted to communities in El Oro and northern Esmeraldas, the effort toward decentralization became more clear in its mission to improve and expand "integrated coastal management by supporting progressive transfer of management to the local level and contributing to sustainable use of coastal resources and improvement in the quality of life within coastal communities" (Herrera Ximénez and Molina Bravo 2008). Integrated coastal management was more actively pursued with participation of communities, as well as proposals to improve community wellbeing through investment and diffusion of information about coastal resources. Several management plans for different custodias were drafted (Bravo 2006, 2006, 2006, 2007), as well as a set of criteria by which communities qualify for a concession (Bravo 2007). Management areas expanded in their geographical

\footnotetext{
9 These findings are not quantified since I realized later on in the research that different informants had different interpretations about what the question meant. When asked if he/she had ever worked on a shrimp pond, those informants who understood fulltime employment answered "no" even if they had worked during several harvests as wage laborers.

${ }^{10}$ All translations from Spanish are my own.
} 
range before the program was absorbed into the Ministry of Environment's Subsecretaría de Gestión de Marina y Costera in 2008, a government agency responsible for all laws pertaining to oceans and coasts, decentralization, management, and conservation of all natural resources within the coastal zone (Herrera Ximénez and Molina Bravo 2008).

Communities interested in obtaining a custodia were required to organize into groups or be "organized ancestral communities" capable of providing maps, a list of members, a management plan detailing sustainable use of mangrove resources, a copy of the association's agreement, names of the officers, and twoyear agreement with an external institution for receiving technical assistance (Bravo 2007). While many government officials interviewed in this research were unclear about the meaning of the term "ancestral" and the criteria by which ancestral is defined, the 41 concessions currently operating today have been granted to local civil society organizations, fishing cooperatives and associations formally recognized by a State agency. Activities considered "sustainable" in the management plans include controlled selective logging for charcoal production, conservation, education, research, reforestation, tourism, artisanal fishing, and culturing of a variety of fish, mollusks, and crustaceans (Bravo 2007).

Since 2000, Isla Costa Rica's custodia has enabled them to achieve the restoration of several mangrove areas, the recuperation of cockles and crabs, and the strengthening of local organization by patrolling and controlling access to gathering grounds (Bravo 2006). In addition to improved catch and shell sizes due to strict management of cockle gathering grounds by rotation, periodic closure, and exclusion of outsiders, the custodias have generated a sense of pride within the community historically marginalized by their isolation and lack of access to education, employment, and infrastructural development (Beitl 2011). However on a broader scale, the very custodias designed to defend artisanal fishers from the loss of mangroves are becoming a source of tension and conflict between members of associations and non-affiliated cockle collectors who are increasingly losing their ground in El Oro Province (Figure 5).
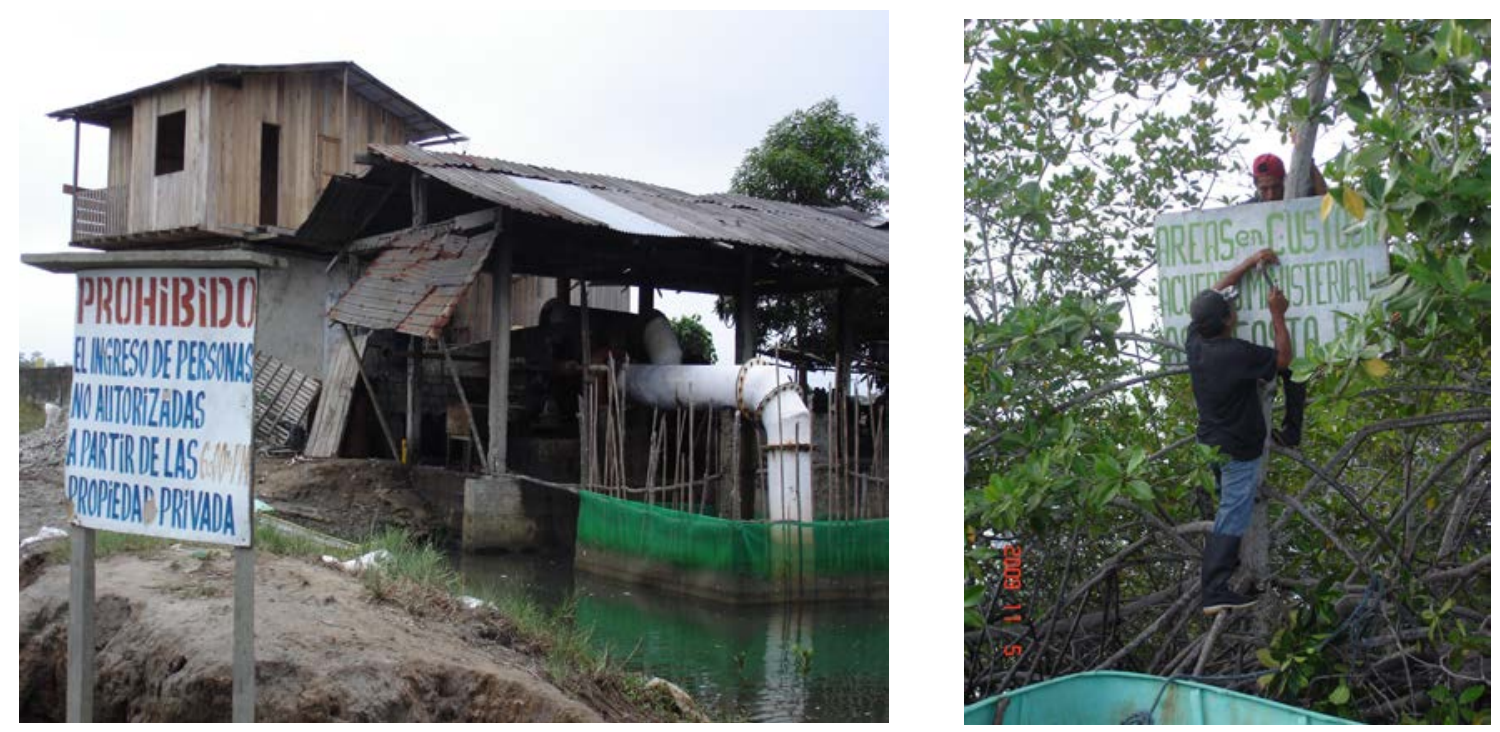

Figure 5: a) private shrimp farm prohibiting access by unauthorized persons b) two association members posting their sign delineating the boundaries of their custodia

In a mangrove landscape carved out by four decades of shrimp aquaculture development, there have been concerns about overexploitation in the cockle fishery. While activists were quick to blame the shrimp industry, many cockle collectors throughout the country generally attributed the decline of the fishery to overexploitation, increased competition, lack of control, lack of other employment opportunities, and too many "outsiders" without the local ecological knowledge to harvest sustainably. In my interviews cockle collectors expressed concern than too many people take small shells without allowing enough time for cockles to grow and reproduce. In Muisne, in particular, many cockle collectors complained about the entry of drug-addicted youth who typically collected shells of all sizes in exchange for drugs to satisfy their fix. When further probed to comment on the situation of mangroves in general, several informants in both provinces recognized the shrimp industry as the culprit. In line with the activists, they acknowledged that shrimp ponds were responsible for the loss of many gathering grounds and the release of effluents into the estuary, an opinion more strongly held in Muisne than in the two El Oro sites. In El Oro, where many custodias have been granted to local associations, cockle collectors expressed concern that they were losing 
their gathering grounds to other compañeros from local associations and other communities that in some cases violently defended their custodias from encroachment and trespassing by outsiders.

As this case study has demonstrated, the custodias were the primary explanation for the loss of gathering grounds in the province of El Oro (see figure 4). The problem was most clear in the case of Las Huacas, a community in the Archipelago Jambelí infamously known in both Isla Costa Rica and Puerto Hualtaco as a "violent community" feared for their fierce defense of their custodias. Several informants commented that the men from Las Huacas have been known to beat trespassers, confiscate catches, and steal personal belongings for years prior to obtaining their legal concession. As one man in Hualtaco said in an interview with me, "I prefer to get (only) 50 cockles than to suffer their abuse" referring to the men in Las Huacas. Other informants commented about the custodias in general, "we have lost our gathering grounds because the people who have concessions have made themselves owners." Another man bitterly stated, "It's all the fault of the custodias that we cockle collectors are now fighting amongst ourselves." Another man argued, "The custodias keep us from working-I do not agree with them." These opinions were further expressed in response to the question about whether they believed everyone has the right to work in mangroves: "We are all Ecuadorians and we all have the right to work in the mangroves, not only those sabidos," he stated implying that members of the associations were "sneaky" and corrupt. ${ }^{11}$ He continued, "The greed...you have to be a socio (member of an association) to work. I don't agree with any institution."

Evidence for the rivalry between independent cockle collectors and members of associations was reinforced by my focus groups in Hualtaco where none of the independent collectors showed up despite personal invitations. In their absence, there was a collective tirade against them by socios accusing them of being uncooperative freeloaders single-handedly responsible for the decline of the fishery. Many socios argued that non-affiliated cockle collectors were the ones who take all the small shells and that all mangroves should be put in community concessions to alleviate these problems of scarcity. They further asserted that only socios should have the right to obtain concessions because they are generally the ones that participate in workshops and invest their time and effort to learn about problems in the fishery while independent collectors do not. Not surprisingly, the incidence of conflict between compañeros was significantly higher in the province of El Oro than in the communities around Muisne where there are no official custodias (table 1).

More neutral opinions came from some of the individual interviews with socios. While some independent collectors expressed a lack of trust in local associations and suspicions that members of the board were all corrupt, many cockle collectors (including socios) expressed that they simply did not agree with the custodias because they have caused so much conflict. As a 45 year-old member of one association without a custodia commented:

I don't agree with the custodias because they don't let us in. We are all Ecuadorians and we have the right, why should we be divided if we are all Ecuadorians? They are so few socios and they have so many areas. It's not fair.

As another 25 year-old member of an association without a custodia of their own put it, "the custodias should protect mangroves against deforestation, but they shouldn't prevent people from working." The general sentiment shared by almost everyone was that everyone should have the right to work in the mangroves, but the frequency of this response was significantly higher in Hualtaco where $97 \%$ believe that mangroves are a public good and benefit to be enjoyed universally (Beitl 2011). Some suggested that rights to mangroves should be granted only to those who fish "responsibly" without destroying the mangroves. As one boy from Isla Costa Rica put it, "We all have to eat," recognizing at the young age of 14 the intricate connection between environment, economics, and subsistence.

\section{Access, enclosure, and political ecology of the mangrove commons}

Following Ribot and Peluso's (2003) steps used for analyzing access to resources, in this section I discuss the power relations and mechanisms of access of the following three groups within the context of policy changes regarding mangroves: 1) shrimp farmers; 2) socios, all cockle collectors who are members of local associations with or without custodias of their own; 3) independent, non-affiliated cockle collectors. In addition to rights-based law (sanctioned by custom, law, and convention) and illegal access (theft or trespassing), Ribot and Peluso argue that access also manifests in ways that are structural and relational, which can influence who benefits from resources. Structural and relational forms of access are established by cultural and political-economic constraints imposed by technology, capital, markets, labor, knowledge, authority, identities, and social relations. In this case study examining the effects of shifting policies and their effects on property rights and access in Ecuadorian mangroves, the benefit under study is the mangrove system and the fishery resources it encompasses. The shrimp farmer has enjoyed the productivity of his shrimp ponds while the artisanal fisher has enjoyed the productivity of a healthy mangrove system in which

\footnotetext{
${ }^{11}$ Sabidos refers to people who are "clever" and knowledgeable in a sneaky or corrupt manner.
} 
benefits are derived from multiple fisheries and other direct uses. Over the last several decades, mechanisms of access and power relations have shifted in response to changing policies affecting the competition between shrimp farmers and cockle collectors over mangrove areas for the benefit of their respective livelihoods.

Of all three groups, shrimp farmers have enjoyed the most power and benefits in the process of appropriating mangroves. This is best reflected by CLIRSEN's statistics in 1995 showing the total coverage of shrimp farms nation-wide exceeded the total coverage of mangroves by over 30,000 hectares (CLIRSENPMRC 2007). Shrimp farmers have exercised their political and economic power, gaining and maintaining access to mangroves based on their technology, financial capital, friendship with authorities, education, and through it all, they have been highly organized. Most importantly, they have enjoyed access to large international markets for mangrove products, particularly farm-raised shrimp, which has taken precedent over national demand for cockles and wild-caught shrimp collected by artisanal fishers. However, as also argued by many activists, many shrimp farmers originally acquired access to mangroves by illegal means.

The Presidential Decree 1391 is designed to regulate the shrimp industry and recuperate several thousands of hectares lost to shrimp farming after decades of haphazard growth and expansion. ${ }^{12}$ According to C-CONDEM and others against the shrimp industry, this new decree is unjust. They argue that shrimp farmers have gained illegal access under all circumstances by operating though coercion or bribes that enticed government officials to turn a blind eye wherever mangroves were being cleared for the construction of shrimp ponds. On the other hand, many shrimp farmers were able to gain access to mangrove areas through a complicated, bureaucratic process due to the heterogeneous nature of the coastal zone and its conflicting jurisdictions. ${ }^{13}$ According to the Supreme Decree 2939-B in 1978, the exploitation of mangroves for shrimp farming was prohibited, but other uses were permitted (Pérez and Robadue 1989). One of my informants suggested that charcoal producers who had legitimate "ancestral" logging rights may have been encouraged by shrimp farmers to clear more areas than they needed for charcoal in order for shrimp farmers to pass inspections by government leasing agencies. Other farmers may have legitimately obtained a lease or title to upland areas and illegally expanded later into adjacent mangrove areas. Others had purchased shrimp farms that had unlawfully encroached mangrove areas under different ownership. While Decree 1391 represents the ways in which shrimp farmers' political power is declining in the face of changing coastal policies, those few shrimp farmers I interviewed in Muisne are in favor since they recognize the benefit of a healthy mangrove system for shrimp aquaculture itself. The fate of the expected recuperation of mangrove areas under the Decree 1391 has yet to be determined, but it is likely that many areas will be entrusted to local associations for mangrove reforestation and the establishment of new custodias. This is in line with the present goal of the Subsecretaría de Gestión de Marina y Costera, which is to expand efforts to conserve mangroves by augmenting the area of custodias from 37,818 to 47,000 hectares for community-based conservation (Rosero Moya and Santillan Salas 2011).

Cockle collectors who are members of local fishing associations have been empowered by the policy changes and the process of receiving a custodia, a form of access acquired by rights-based law. Their mechanisms for gaining and maintaining access have been facilitated by policy changes which also have enabled them to strengthen their political power through social networking, cross-scale institutional collaborations, and on the basis of their identity as "ancestral users." For example, based on their social relations, their identity as "ancestral users," and access to the proper government authorities through their participation in civil society, the Association in Isla Costa Rica was able to secure a concession of 579 hectares in the year 2000. In 2005, when a local shrimp farmer attempted to clear mangroves to illegally expand his operation, the community concession allowed socios from Isla Costa Rica to defend their property rights, uphold the law, and continue deriving benefits from mangrove fisheries for their community. Along with the legal backing has come a strong sense of empowerment which has further encouraged local participation in government activities as socios are beginning to feel more valued and less intimidated by government authorities and other outsiders. As their local organizations built their social and political capital through gaining access to authorities, they have effectively defended mangroves from further destruction and established management plans that promote sustainable fishing within the boundaries of the custodia at the expense of excluding independent cockle collectors (Beitl 2011).

Independent cockle collectors have had little or no political and economic power to gain, control, or maintain access to the mangrove cockle fishery in Ecuador. Since they have been excluded from the political process, their access to gathering grounds has been significantly reduced as more public areas are enclosed by custodias. Those who are not displaced by problems of overexploitation in the remaining open-access areas may gain and maintain access by a special category of illegal means, what Ribot and Peluso refer to as "rights-denied access." Cockle collectors who have trespassed to collect in the custodias or near shrimp ponds, either to steal shrimp directly from the ponds or to simply collect shells from the mangrove fringes surrounding shrimp ponds have also gained access by illegal means. Without any institutional support, and

\footnotetext{
12 Passed in October of 2008, March 31, 2010 was the last day for shrimp farmers to submit their application including a plan for the reforestation of a certain percentage of their farm in order to legalize their occupation of mangrove areas.

${ }^{13}$ See Pérez and Robadue (1989) for a description of the process.
} 
because of their lack of interest in joining any institution, independent cockle collectors are likely to disappear into alternative livelihoods, as collecting cockles becomes less profitable or dangerous for the prospect of violent confrontation with shrimp farmers or associations defending their custodia.

\section{Conclusion}

The political ecology approach employed in this study has illustrated the ways in which the shifting nature of access within the mangrove commons has corresponded with policy change and contributed to problems of conflict, overfishing, and a tragedy of common property rights. The appropriation of mangroves by way of shrimp farming or community-based concession has resulted in an unequal flow of benefits. As a common property arrangement, custodias are collectively owned by an identifiable group of individuals (Satria, Matsuda, and Sano 2006), which, very much like shrimp farms, are a form of private property. While custodias were designed to overcome the problem of the commons, like shrimp farms, they have also subtracted from the welfare of the other users and have occasionally resulted in illegal trespassing or theft, further epitomizing the problem of the commons (Buck 1998; Ostrom et al. 1999) and illustrating the contradictions of the term "common property" for its ability to include and exclude simultaneously (O'Flaherty 2003). As an ecological consequence, shells collected outside of the managed areas of the custodias tend to be fewer and smaller in size, suggesting that the common property arrangements have simply deflected the problem of overexploitation to open-access areas where independent collectors compete for increasingly scarce resources (Beitl 2011). A political ecology of the commons addresses the changing nature of access and structural inequities depending on the political agents in power (Ribot and Peluso 2003) and the ways in which common property institutions themselves may function as political agents in their own right (Reddy 2002). These considerations may also be relevant to other community-managed marine areas in other parts of the world (Gallardo Fernandez and Friman 2011).

The case of the mangrove cockle fishery further demonstrates that overfishing appears to be related to a long legacy of habitat fragmentation by the shrimp industry and subsequent enclosures of remaining mangrove forest fragments by custodias ultimately giving rise to new social tensions. This study contributes to understanding about the ways in which material struggles over resources and structural inequity can also manifest politically in collective actions and common property solutions to landscape degradation with significant implications for ecological outcomes. Considering questions of shifting access and the tragedy of enclosures, it is necessary to ask whether the policy changes in Ecuador are effectively moving in the direction toward sustainability, participation, and integrated coastal management. It is expected that the new policies will contribute to mangrove recovery in some areas, but questions still remain about how new areas will be divided and who will benefit from access to them. As more custodias are established in the near future, independent fishers will continue to be displaced by overexploitation within open-access areas and forced to make a choice between engaging in illegal access or leaving the fishery all together.

On the other hand, the establishment of custodias on the Ecuadorian coast has great potential to contribute to the sustainable development of mangrove fisheries, and policy makers must consider the needs of non-associated independent fishers to facilitate their access and evade a tragedy of enclosures. Some government officials have argued for a need to mandate the participation by all cockle collectors in local associations. Before such policies are considered, further research should seek to alleviate the growing tensions by verifying claims made by association members and certain government officials that independent cockle collectors actually harvest in an unsustainable manner (Beitl 2012). Furthermore, incorporating independent cockle collectors who are distrustful of institutions presents the danger of coercive collective action and the creation of citizenship by government according to its own ideology about 'the common good'. Foucault (1991: 94-95) contends this is "essentially obedience to the law" by citizens in order for the government to maintain its "principality" or power in a Machiavellian sense. Such authoritarian forms of governance under the guise of "progressive sustainable development" that ignore the role of local knowledge, heterogeneity, and individual rights to self-determination are likely to backfire (Scott 1998).

One final concern raised by Ribot and Peluso (2003) is that when policies shift toward greater citizen participation and decentralization, they sometimes fail to allocate property rights to local people, resulting in ambiguity over access. This has not been the case in the Ecuadorian cockle fishery. Local associations did indeed receive very clear rights to their new mangrove concessions, but they did so at the expense of further marginalizing independent cockle collectors with significant implications for the sustainability of the fishery. If coastal policy in Ecuador is to truly move in the direction of conservation-oriented and "participatory" policies then it must first address issues of equity and access. 


\section{References}

Acharya, G. 2002. Life at the margins: the social, economic, and ecological importance of mangroves. Madera y Bosques 8 (1): 53-60.

Acheson, J. 1987. The lobster fiefs revisited: economic and ecological effects of territoriality in the Maine lobster fishery. In B.J. McCay and J.M. Acheson (eds.) The question of the commons: the culture and ecology of communal resources. Tucson: University of Arizona Press. Pp. 37-65.

Acheson, J., and J.F. Brewer. 2003. Changes in the territorial system of the Maine lobster industry. In N. Dolsak and E. Ostrom (eds.) The Commons in the new millennium: challenges and adaptation. Cambridge, MA: MIT Press. Pp. 37-59.

Acosta, A., and E. Martinez. 2009. Derechos de la naturaleza: el futuro es ahora. Quito, Ecuador: AbyaYala.

Agrawal, A. 2001. Common property institutions and sustainable governance of resources. World Development 29(10): 1649-1672.

Agrawal, A. and C.C. Gibson. 1999. Enchantment and disenchantment: the role of community in natural resource conservation. World Development 27(4): 629-649.

Armitage, D. 2002. Socio-institutional dynamics and the political ecology of mangrove forest conservation in central Sulawesi, Indonesia. Global Environmental Change-Human and Policy Dimensions 12(3): 203-217.

Bailey, C. 1988. The social consequences of tropical shrimp mariculture development. Ocean and Shoreline Management 11(1): 31-44.

Barbier, E.B. 2003. Habitat-fishery linkages and mangrove loss in Thailand. Contemporary Economic Policy 21(1): 59-77.

Beitl, C.M. 2011. Cockles in custody: the role of common property arrangements in the ecological sustainability of mangrove fisheries on the Ecuadorian coast. International Journal of the Commons 5(2): 485-512. Online: http://tinyurl.com/c2gv2ey

Beitl, C.M. 2012. Beyond collective action: a multi-scale analysis of sustainability in the mangrove fishery commons of coastal Ecuador. Ph.D. Dissertation. Athens, USA: University of Georgia.

Beitl, C.M., and A. Cruz. 2010. Custodias del manglar y monitoreo comunitario del recurso Concha Prieta (Anadara tuberculosa y A. similis) en la Isla Costa Rica, El Oro, Ecuador. In Resultados del monitorero comunitario con la Asociacion de Costa Rica Diciembre 2009 - Junio de 2010. El Oro, Ecuador.

Berkes, F. 1996. Social systems, ecological systems, and property rights. In S. Hanna, C. Folke and K.-G. Mäler (eds.) Rights to nature: ecological, economic, cultural, and political principles of institutions for the environment. Washington, D.C.: Island Press. Pp. 87-107.

Berkes, F. 2005. Commons theory for marine resource management in a complex world. Senri Ethnological Studies 67: 13-31.

Biersack, A., and J.B. Greenberg (eds.) 2006. Reimagining political ecology. Durham: Duke University Press.

Blaikie, P.M., and H.C. Brookfield. 1987. Land degradation and society. London and New York: Methuen.

Bordero, A., and R. Retamales. 2003. Ecuador. In D. J. Macintosh and E. C. Ashton (eds.) Report on the South America regional workshop on the sustainable management of mangrove forest ecosystems, Fortaleza, Ceará, Brazil. Pp. 14-18.

Brander, L.M., R. Florax, and J.E. Vermaat. 2006. The empirics of wetland valuation: a comprehensive summary and a meta-analysis of the literature. Environmental \& Resource Economics 33(2): 223-250.

Bravo, M. 2006. Actualización del plan de manejo de la concesión de manglar de la Asociación de Cangrejeros 6 de Julio, Naranjal - Guayas - Ecuador. In Programa de manejo de recursos costeros. Guayaquil, Ecuador. Pp. 1-53.

Bravo, M. 2006. Actualización del plan de manejo del manglar concesionado a la Asociación de Pescadores Artesanales, Mariscadores y Afines Costa Rica: Archipiélago de Jambelí. In Programa de manejo de recursos costeros, Procedimiento CCI No. PMRC-035-2005. Guayaquil, Ecuador. Pp. 1-61.

Bravo, M. 2006. Actualización del plan de manejo para el uso sostenible y custodia de manglar de la Comunidad Santa Rosa, Cantón Eloy Alfaro, Provincia Esmeraldas. In Programa de manejo de recursos costeros, Procedimiento CCI No. PMRC-035-2005. Guayaquil, Ecuador. Pp. 1-38.

Bravo, M. 2007. Analisis de la base legal para el otorgamiento de las concesiones de manglar, responsabilidades jurídicas respecto a talas en zonas concesionadadas, y competencias para expedir los acuerdos de uso sustentable y custodia del manglar. In Programa de manejo de recursos costeros, Procedimiento CCI No. PMRC-035-2005 Actualización de los planes de manejo de las concesiones del manglar. Guayaquil, Ecuador. Pp. 1-46. 
Bravo, M. 2007. Analisis de los acuerdos de uso sustentable ortogados a usuarios tradicionales para la protección y manejo del ecosistema manglar: Estudios de caso de las Concheras 18 de Octubre (Provincia Esmeraldas); Cangrejeros Seis de Julio (Provincia Guayas) y Mariscadores Costa Rica (Provincia el Oro). In Programa de manejo de recursos costeros, Procedimiento CCI No. PMRC-0352005 Actualización de los planes de manejo de las concesiones del manglar. Guayaquil, Ecuador. Pp. $1-50$.

Bromley, D.W., and D. Feeny. 1992. Making the commons work: theory, practice, and policy. San Francisco: Institute for Contemporary Studies.

Bryant, R. 1992. Political ecology: an emerging research agenda in third-world studies. Political Geography 11(1): 12-36.

Buck, S.J. 1998. The global commons: an introduction. Washington, DC: Island Press.

C-CONDEM. 2007. Certificando la destrucción: análisis integral de la certificación orgánica a la acuacultura industrial de camarón en Ecuador. Quito, Ecuador: Corporación Coordinadora Nacional para la Defensa del Ecosistema Manglar.

Christie, P. 2005. Is integrated coastal management sustainable? Ocean and Coastal Management 48(3-6): 208-232.

Cinner, J.E. 2005. Socioeconomic factors influencing customary marine tenure in the Indo-Pacific. Ecology and Society 10(1): Online: http://www.ecologyandsociety.org/vol10/iss1/art36/

CLIRSEN-PMRC. 2007. Actualización del estudio multitemporal de manglares, camaroneras y áreas salinas en la costa continental Ecuatoriana al año 2006. Guayaquil, Ecuador: Centro de Levantamientos Integrados de Recursos Naturales por Sensores Remotos \& the Programa de Manejo de Recursos Costeros.

Coello, S., D.V. Burgos, and R Alemán. 2008. Evaluación del desempeño de los acuerdos de uso sustentabale y custodia de manglar de la zona costera del Ecuador. valuación del desempeño de los acuerdos de uso sustentabale y custodia de manglar de la zona costera del Ecuador. Guayaquil, Ecuador: Ministerio del Ambiente del Ecuador - Conservación Internacional - Unión Mundial para la Naturaleza (UICN) - Comisión Mundial de Áreas Protegidas de UICN - Programa de apoyo a la gestión descentralizada de los recursos naturales en las tres provincias del norte del Ecuador (PRODERENA) - Ecobiotec. Pp. 1-52.

Cruz-Torres, M.L. 2000. 'Pink gold rush': shrimp aquaculture, sustainable development, and the environment in northwestern Mexico. Journal of Political Ecology 7: 63-90. Online: http://jpe.library.arizona.edu/volume_7/Cruz00.pdf

Curran, S. R., and T. Agardy. 2002. Common property systems, migration, and coastal ecosystems. Ambio 21(4): 303-305.

Dewalt, B.R., P Vergne, and M. Hardin. 1996. Shrimp aquaculture development and the environment: People, mangroves and fisheries on the Gulf of Fonesca, Honduras. World Development 24(7): 11931208.

Dolsak, N., and E. Ostrom. 2003. The challenges of the commons. In N. Dolsak and E. Ostrom (eds.) The commons in the new millennium: challenges and adaptation. Cambridge, MA: MIT Press. Pp. 3-34.

Ecobiotec. 2009. Situación actual: Concesiones de manglar en la reserva ecológica Cayapas Mataje y el área de influencia de la reserva manglares Churute y estado de conservación del manglar de la Isla Mondragón. Report to USAID-Ecuador. Guayaquil. Ecuador. Pp. 1-41.

Elao, R., and G. Guevara. 2006. Las poblaciones de moluscos en el estuario del Cojimíes. Ecocostas. Online: www.ecocostas.org.

Feeny, D., F. Berkes, B.J. McCay, and J.M. Acheson. 1990. Tragedy of the commons: twenty-two years later. Human Ecology 18(2): 1-19.

Forsyth, T. 2003. Critical political ecology: the politics of environmental science. London: Routledge.

Foucault, M. 1991. Governmentality. In G. Burchell, C. Gordon and P. Miller (eds.) The Foucault effect: studies in governmentality. Chicago: University of Chicago Press. Pp. 87-104.

Gallardo Fernandez, G., and E. Friman. 2011. New marine commons along the Chilean coast - the management areas (MAs) of Peñuelas and Chigualoco. International Journal of the Commons 5(2): 433-458. Online: http://tinyurl.com/6wafh4q

Gibson, C.C., M.A. McKean, and E. Ostrom. 2000. People and forests: communities, institutions and governance. Cambridge: MIT Press.

Glaser, M. 2003. Interrelations between mangrove ecosystem, local economy, and social sustainability in the Caeté Estuary, North Brazil. Wetlands Ecology and Management 11(4): 265-272.

Gordon, H.S. 1954. The economic theory of a common-property resource: the fishery. The Journal of Political Economy 62(2): 124-142.

Greenberg, J.B., and T.K. Park. 1994. Political ecology. Journal of Political Ecology 1(1): 1-12. 
Greenberg, J.B. 2006. The political ecology of fisheries in the upper Gulf of California. In A. Biersack and J. B. Greenberg (eds.) Reimagining Political Ecology. Durham: Duke University Press. Pp. 121-148.

Guest, G.S. 1999. Global vision and local lives: policy, participation, and coastal management in Ecuador. Culture and Agriculture 21(1): 1-13.

Guest, G.S. 2000. Shrimp, poverty, and marine resources on the Ecuadorian coast: a multi-level analysis of fishing effort in the Rio Verde Estuary. Ph.D. Dissertation. Athens, GA: University of Georgia.

Gunawardena, M., and J.S. Rowan. 2005. Economic valuation of a mangrove ecosystem threatened by shrimp aquaculture in Sri Lanka. Environmental Management 36(4): 535-550.

Hanna, S., C. Folke, and K.-G. Mäler. 1996. Rights to nature: ecological, economic, cultural, and political principles of institutions for the environment. Washington, D.C.: Island Press.

Hanna, S., and M. Munasinghe (eds.) 1995. Property rights and the environment: social and ecological issues. Washington, DC: Beijer International Institute of Ecological Economics and the World Bank.

Hardin, G. 1968. Tragedy of the commons. Science 162: 1243-1248.

Herrera Ximénez, M.D., and E. Molina Bravo. 2008. Programa de manejo de recursos costeros. Nov. 25-28, 2008. Varadero, Cuba. Online: http://tinyurl.com/7bbhe4e

INP. 1971. Segundo censo pesquero nacional. Guayaquil, Ecuador: Instituto Nacional de Pesca, Instituto Nacional de Estadistica, Direccion General de Pesca.

Jermyn, L. 2000. White gold. E Magazine: The Environmental Magazine 11(3): 10-12.

Johannes, R.E. 1978. Traditional marine conservation methods in Oceania and their demise. Annual Review of Ecology and Systematics 9: 349-364.

Johannes, R.E. 2002. The renaissance of community-based marine resource management in Oceania. Annual Review of Ecology and Systematics 33: 317-40.

Kovacs, J.M. 1998. Assessing mangrove use at the local scale. Landscape and Urban Planning 43(4): 201208.

Lu, F.E. 2001. The common property regime of the Huaorani Indians of Ecuador: implications and challenges to conservation. Human Ecology 29(4): 425-447.

Lutz, C.G. 2006. Still evolving: global shrimp farming continues to set a course in pursuit of sustainability. Aquaculture Magazine 32(3): 21-25.

Macintosh, D.J., and E.C. Ashton. 2004. Principles for a code of conduct for the management and sustainable use of mangrove ecosystems. Version 10 of March 2005. World Bank. online: http://tinyurl.com/787ofc5.

MacKenzie, C.L. 2001. The fisheries for mangrove cockles, Anadara spp., from Mexico to Peru, with descriptions of their habitats and biology, the fishermen's lives, and the effects of shrimp farming. Marine Fisheries Review 63(1): 1-39.

Martinez-Alier, J. 2001. Ecological conflicts and valuation: mangroves versus shrimps in the late 1990s. Environment and Planning C: Government and Policy 19(5): 713-728.

McCay, B.J., and J.M. Acheson. 1987. The question of the commons: The culture and ecology of communal resources. Tucson: University of Arizona Press.

McKean, M.A. 2000. Common property: What is it, what is it good for and what makes it work? In C.C. Gibson, M.A. McKean and E. Ostrom (eds.) People and forests: communities, institutions and governance. Cambridge, MA: MIT Press.

Mera Orcés, V. 1999. Género, manglar, y subsistencia. Quito, Ecuador: Abya Yala.

Mora, E., and J. Moreno. 2009. La pesqueria artesanal del recurso concha (Andara tuberculosa y A. similis) en la costa Ecuatoriana durante el 2004. Boletín Cientifico y Técnico 20(1): 1-16.

Mora, E., J. Moreno, and V. Jurado. 2009. La pesquería artesanal del recurso concha en las zonas de Esmeraldas y El Oro, durante el 2008. Boletín Cientifico y Técnico 20(2): 17-36.

Murray, G., T. Johnson, B.J. McCay, M. Danko, K. St. Martin, and S. Takahashi. 2010. Creeping enclosure, cumulative effects and the marine commons of New Jersey. International Journal of the Commons 4(1): 367-389. Online: http://www.thecommonsjournal.org/index.php/ijc/article/view/148

Mychalejko, Cyril 2008. Ecuador's constitution gives rights to nature. Upside Down World, September 25, 2008. Online: http://tinyurl.com/7y9rvt6

North, D.C. 1990. Institutions, institutional change, and economic performance: the political economy of institutions and decisions. Cambridge, UK: Cambridge University Press.

O'Flaherty, R.M. 2003. The tragedy of property: ecology and land tenure in southeastern Zimbabwe. Human Organization 62(2): 178-190.

Ocampo-Thomason, P. 2006. Mangroves, people and cockles: impacts of the shrimp-farming industry on mangrove communities in Esmeraldas Province, Ecuador. In C. T. Hoanh, T. P. Tuong, J. W. Gowing 
and B. Hardy (eds.) Environment and livelihoods in tropical coastal zones: managing agriculturefishery-aquaculture conflicts. Oxon, UK: CAB International. Pp. 140-153.

Odum, H.T., and J.E. Arding. 1991. Emergy analysis of shrimp mariculture in Ecuador. Narragansett, RI: Coastal Resources Center, University of Rhode Island.

Olsen, S.B., and P. Christie. 2000. What are we learning from tropical coastal management experiences? Coastal Management 28(1): 5-18.

Olsen, S.B., E Ochoa, and D Robadue. 2003. Ecuador: establishing a coastal management program in an unstable system. In S. B. Olsen (ed.) Crafting coastal governance in a changing world. Coastal Management Report \#2241. Narragansett, RI: Coastal Resources Center, University of Rhode Island.

Ostrom, E. 1990. Governing the commons: evolution of institutions for collective action. Cambridge, UK: Cambridge University Press.

Ostrom, E., J. Burger, C.B. Field, R.B Norgaard, and D. Policansky. 1999. Revisiting the commons: local lessons, global challenges. Science 284: 278-282.

Parks, P.J., and M. Bonifaz. 1994. Nonsustainable use of renewable resources: mangrove deforestation and mariculture in Ecuador. Marine Resource Economics 9: 1-18.

Paulson, S., and L.L. Gezon (eds.) 2005. Political ecology across spaces, scales, and social groups. New Brunswick, NJ: Rutgers University Press.

Peet, R., and M. Watts. 2004. Liberation ecologies: environment, development, social movements. 2nd ed. London and New York: Routledge.

Peluso, N., and M. Watts, eds. 2001. Violent Environments. Ithaca and London: Cornell University Press.

Pérez, E., and Robadue, D. (1989). Institutional aspects of shrimp mariculture in Ecuador. In Olsen, S. and Arriaga, L. (eds.) A sustainable shrimp mariculture industry for Ecuador. Narragansett, RI: Coastal Resources Center, University of Rhode Island. Pp. 71-88.

Peters, P. 1987. Embedded systems and rooted models: The grazing lands of Botswana and the "commons" debate. In B.J. McCay and J.M. Acheson (eds.) The question of the commons: the culture and ecology of communal resources. Tucson: University of Arizona Press. Pp. 171-194.

Pollnac, R.B., and J. Johnson. 2005. Folk management and conservation of marine resources: towards a theoretical and methodological assessment. In N. Kishigami, J. M. Savelle and K. M. Hakubutsukan (eds.) Indigenous use and management of marine resources. Suita, Osaka: National Museum of Ethnology.

Primavera, J.H. 1997. Socio-economic impacts of shrimp culture. Aquaculture Research 28(10): 815-827.

Reddy, S.P. 2002. Communal forests, political spaces: territorial competition between common property institutions and the state in Guatemala. Space \& Polity 6(3): 271-287.

Ribot, J.C., and N.L. Peluso. 2003. A theory of access. Rural Sociology 68(2): 153-181.

Richards, M. 1997. Common property resource institutions and forest management in Latin America. Development and Change 28: 95-117.

Robadue, D. (ed.) 1995. Eight years in Ecuador: the road to integrated coastal management. CRC technical report \#2088. Narrangensett, RI: Coastal Resources Center, University of Rhode Island.

Ronnback, P. 1999. The ecological basis for economic value of seafood production supported by mangrove ecosystems. Ecological Economics 29(2): 235-252.

Rosero Moya, K., and C. Santillan Salas. 2011. Ministerio del ambiente entrega acuerdo de uso sustentable y custodia de manglar. Boletin No. 498 09-06-2011 http://www.ambiente.gob.ec/?q=node/1952 (accessed: 8/14/2011).

Ruttan, L. 1998. Closing the commons: cooperation for gain or restraint? Human Ecology 26(1): 43-66.

Satria, A., Y. Matsuda, and M. Sano. 2006. Contractual solution to the tragedy of property right in coastal fisheries. Marine Policy 30(3): 226-236.

Scott, J.C. 1998. Seeing like a state: how certain schemes to improve the human condition have failed. New Haven: Yale University Press.

Snedaker, S.C. 1986. Traditional uses of South American mangrove resources and the socio-economic effect of ecosystem changes. In P. Kunstadter, E. Bird and S. Sabhrasi (eds.) Man in the mangroves. Tokyo: The United Nations University.

Southgate, D.D., and M.D. Whitaker. 1994. Economic progress and the environment: one developing country's policy crisis. New York: Oxford University Press.

Stonich, S., and P. Vandergeest. 2001. Violence, environment, and industrial shrimp farming. In N. L. Peluso and M. Watts (eds.) Violent environments. Ithaca: Cornell University Press.

Stonich, S. 1995. The environmental quality and social justice implications of shrimp mariculture development in Honduras. Human Ecology 23(2): 143-168. 
Stonich, S.C., and C. Bailey. 2000. Resisting the blue revolution: contending coalitions surrounding industrial shrimp farming. Human Organization 59(1): 23-36.

Stott, P., and S. Sullivan. 2000. Political ecology: science, myth, and power. New York: Oxford University Press.

Thomas, F.R. 2001. Remodeling marine tenure on the atolls: a case study from western Kiribati, Micronesia. Human Ecology 29(4): 399-423.

Upadhyay, V.P., R. Ranjan, and J.S. Singh. 2002. Human-mangrove conflicts: the way out. Current Science 83(11): 1328-1336.

Wagner, J., and A. Davis. 2004. Property as a social relation: rights of "kindness" and the social organization of lobster fishing among northeastern Nova Scotian Scottish Gaels. Human Organization 63(3): 320333.Wagner, J. and Talakai, M. 2007. Customs, commons, property, and ecology: case studies from Oceania. Human Organization 66(1): 1-10.

Walters, B.B., P. Rönnbäck, J.M. Kovacs, B. Crona, S.A. Hussain, R. Badola, J.H. Primavera, E. Barbier, and F. Dahdouh-Guebas. 2008. Ethnobiology, socio-economics and management of mangrove forests: a review. Aquatic Botany 89(2): 220-236.

Wolf, E. 1972. Ownership and political ecology. Anthropological Quarterly 45(3): 201-205.

Zerner, C. (ed.) 2000. People, plants, \& justice: the politics of nature conservation. New York: Columbia University Press.

\begin{abstract}
After decades of mangrove deforestation for the development of shrimp farming, the Ecuadorian state began to officially recognize the ancestral rights of traditional users of coastal mangrove resources in the late 1990s. This article traces the trajectory of coastal policy change and the transformation of mangrove tenure regimes from an implicit preference for shrimp aquaculture to a focus on conservation and sustainable development with greater community participation through the establishment of community-managed mangrove areas called custodias. I argue that while the custodias have empowered local communities in their struggle to defend their livelihoods and environment against the marginalizing forces of global shrimp aquaculture, the implementation of common property arrangements for mangrove fishery management has changed the nature of property rights, the distribution of resources, and social relations among collectors of mangrove cockles (Anadara tuberculosa and A. similis). I suggest a need to develop a political ecology of the commons, an analytical approach applied here to examine the fundamental shift in the nature of the struggle over mangrove resources, from artisanal fishers versus shrimp farmers to a struggle between compañeros: members of associations versus independent cockle collectors. Such a shift in the struggle over resources threatens to undermine the sustainability of the fishery. I conclude that shifting access may be an important underlying factor contributing to a tragedy of enclosures in Ecuador's mangrove cockle fishery.
\end{abstract}

Keywords: political ecology; property rights; common property; access; tragedy of enclosures; shrimp aquaculture; mangroves; artisanal fisheries; Anadara spp., Ecuador 


\section{Résumé}

A la fin des années 1990, l'Equateur a engagé des actions pour la reconnaissance des droits coutumiers des usagers de la mangrove, cela après des décennies de déforestation au profit du développement de l'élevage des crevettes. Le présent article retrace l'histoire des changements des politiques côtières et celle de la transformation des régimes de propriétés des mangroves depuis le développement de l'aquaculture jusqu'aux tentatives récentes de conservation de cet écosystème; la recherche d'une gestion durable de la mangrove passe aujourd'hui par des formes de concertation et notamment la création des custodias - zones de pêche gérées collectivement par les communautés côtières. Je souhaite démontrer que si les custodias ont donné un certain pouvoir aux communautés locales au travers de la défense de leurs environnement et mode de vie traditionnel, la mise en place de ces régimes de propriété collective a changé la nature des droits de propriétés, la distribution des ressources et les relations sociales entre ramasseurs de coquillages (Anadara tuberculosa and A. similis). Je suggère, dans cet article, qu'il est nécessaire d'aborder la question de la gestion des ressources des mangroves au travers du prisme de l'écologie politique des biens communs et d'une approche analytique appliquée ; on pourra dés lors examiner un déplacement fondamental des conflits, d'un conflit entre pêcheurs traditionnels vs industriels de la crevette vers un conflit entre membres des associations de gestion communautaires vs ramasseurs de coquillages indépendants; ce déplacement pouvant grandement compromettre la viabilité de la pêche. Je conclus que le changement des droits d'accès à la ressource est un facteur qui peut potentiellement contribuer à une tragédie de la privatisation de la pêche de la coquille brune en Equateur.

Mots-clés: écologie politique, droits de propriété, accès aux biens communs; tragédie de privatisation, aquaculture des crevettes, pêche artisanale, Anadara spp., mangroves, Equateur

\section{Resumen}

Después de décadas de deforestación de los manglares en favor del desarrollo de la industria camaronera, en los últimos años de los 90s, Ecuador empezó a reconocer los derechos consuetudinarios que tienen los "usuarios ancestrales" de los recursos del manglar. En este artículo se muestra la trayectoria de cambio en las políticas costeras y la transformación de los regímenes de tenencia de manglares desde una preferencia por el desarrollo de la acuacultura, hacia la conservación y el desarrollo sostenible con mayor participación de las comunidades costeras mediante el establecimiento de la custodia y la gestión comunitaria. Yo propongo que las custodias han dado poder político a las comunidades locales en su lucha por defender sus medios de subsistencia y del medio ambiente en contra de las fuerzas de marginación que sobre ellas ejerce la acuacultura global. Sin embargo, la reconfiguración de las instituciones de propiedad común ha alterado los esquemas de los derechos de propiedad, la distribución de los recursos, y las relaciones sociales entre los recolectores de concha prieta (Anadara tuberculosa and A. similis). Sugiero la necesidad de desarrollar un marco de ecología política de los comuneros, una aplicación fundamental para ilustrar y entender la evolución de la lucha por los recursos del manglar, misma que se ha transformado de un conflicto entre los pescadores artesanales frente a los productores de camarón, hasta una lucha entre compañeros: los socios contra los concheros independientes, lo anterior, podría socavar la sostenibilidad de la pesquería. El cambio en los derechos de acceso al recurso es un factor que potencialmente puede contribuir a una tragedia en la privatización de la pesquería para la concha prieta en el Ecuador.

Palabras clave: ecología política; derechos de propiedad; propiedad común; acceso; tragedia de la privatización; acuacultura del camarón; pesquerías artesanales; Anadara spp., manglares; Ecuador 